\title{
Use of Lactobacillus farciminis to improve antioxidant status of Tuj lambs
}

\author{
O. Durna Aydın ${ }^{1 \#}$, G. Yıldız², O. Merhan ${ }^{3}$, S. Ulufer Bulut ${ }^{4}$, A. Kanıcı Tarhane ${ }^{5}$, \\ P. Ambarcıoğlu ${ }^{6}$, M. Sezer ${ }^{7}$ \& E. Akyüz ${ }^{7}$ \\ ${ }^{1}$ Kafkas University, Veterinary Faculty, Animal Nutrition and Nutritional Diseases Department, 36040, Kars, Turkey. \\ ${ }^{2}$ Ankara University, Veterinary Faculty, Animal Nutrition and Nutritional Diseases Department, 06830, Ankara, Turkey \\ ${ }^{3}$ Kafkas University, Faculty of Veterinary Medicine, Department of Biochemistry, 36040, Kars, Turkey \\ ${ }^{4}$ Kafkas University, Vocational School of Kağızman, Department of Pharmacy Services, 36700, Kars, Turkey \\ ${ }^{5}$ Kafkas University, Faculty of Veterinary Medicine, Department of Pharmacology and Toxicology, 36040, Kars, Turkey \\ ${ }^{6}$ Mustafa Kemal University, Faculty of Veterinary Medicine, Department of Biostatistics, 31060, Hatay, Turkey \\ ${ }^{7}$ Kafkas University, Faculty of Veterinary Medicine, Department of Internal Medicine, 36040, Kars, Turkey
}

(Received 25 May 2021; Accepted 23 June 2021; Published 21 August 2021)

\author{
Copyright resides with the authors in terms of the Creative Commons Attribution 4.0 South African Licence. \\ See: http://creativecommons.org/licenses/by/4.0/za \\ Condition of use: The user may copy, distribute, transmit and adapt the work, but must recognise the authors and the South African \\ Journal of Animal Science.
}

\begin{abstract}
The aim of this study was to investigate the effects of Lactobacillus farciminis on growth traits and antioxidant status in preweaning and postweaning Tuj lambs. Twenty lambs were divided into four groups, regardless of gender, with a mean live weight of $7.81 \pm 0.50 \mathrm{~kg}$. At the start of the experiment, the average age of the lambs was seven days. During the six-week preweaning period, control (C) lambs were fed with colostrum only, and Lactobacillus farciminis was given orally to the treated lambs at $1 \mathrm{~g} /$ day/lamb (L1), 2 $\mathrm{g} /$ day/lamb (L2) or $4 \mathrm{~g} /$ day/lamb (L3). The experiment continued for a total of 22 weeks. During the first six weeks, bodyweight (BW) increased significantly in L1 at the sixth week. Also during this period, bodyweight gain (BWG) in L2 at 2 - 3 weeks and in L3 at $5-6$ weeks differed from C. In the subsequent period, BW and BWG were not affected by probiotic supplementation. The effects of probiotic supplementation on malondialdehyde (MDA), nitric oxide (NO), superoxide dismutase (SOD), glutathione peroxidase (GPx), and catalase (CAT) were significant throughout the experiment, with the effect on glutathione (GSH) also being important in the first six weeks. Thus, Lactobacillus farciminis provided orally to Tuj breed lambs could be used to improve their antioxidant status without compromising growth.
\end{abstract}

Keywords: bodyweight, growth rate, probiotic

\#Corresponding author: odurna36@gmail.com

\section{Introduction}

When ruminants are born, their digestive organs are not fully developed (Diler, 2007). Although the digestive tract is sterile in newborn ruminants, Escherichia coli (E. coli) can colonize rapidly in all regions of the digestive tract within the first eight hours of birth, and Lactobacillus and Streptococcus species can be detected in the digestive tract at 24 hours. In a healthy animal, Lactobacillus spp colonizes rapidly instead of coliforms (E. coli, etc.). However, if the animal is not healthy, coliform bacteria can colonize in the digestive tract more so than Lactobacillus spp, and this causes diarrhoeal cases. This diarrhoea is often encountered in young animals and results in serious economic losses (Wallace \& Newbold, 2007).

lonophore group antibiotics (monensin, lasalocid, etc.) can be added to animal feeds as a growth factor to control pathogenic microorganisms in the digestive system of ruminants and to prevent adverse effects on rumen fermentation. However, the use of these antibiotics, while preventing the reproduction of pathogenic bacteria in the intestine, inhibits the reproduction of beneficial microorganisms (Aşan \& Özcan, 2006). Moreover, the use of antibiotics in feed promotes the development of bacterial resistance. Antibiotics consumed by animals can affect people that consume the animal products, because antibiotic residues may remain in them (Aarestrup et al., 2000). The emergence of antibiotic resistant pathogens led to a prohibition of antibiotic use in animal feed to promote growth. Thus, probiotics, prebiotics, enzymes, organic acids, and products such as essential oils have seen increased use as feed additives in place of antibiotics (Cimrin et al., 2020; Durna Aydin et al., 2021). 
Probiotics have been defined as 'living organisms that, provided that they are in sufficient amount, bring health benefits to their host' (FAO \& WHO, 2002). Typical probiotics are live bacteria, fungi and yeasts, characterized as being mostly gram positive, and facultative anaerobes that take up residence in the digestive tract and are not absorbed by the host animal. They have antagonistic effects against pathogenic microorganisms (Antunovic et al., 2005). Probiotics have proven their efficacy when utilized as dietary factors for the regulation of gastrointestinal functions. For example, probiotics can be used to alleviate lactose intolerance, fight various types of diarrhoea and urogenital infections, reduce cholesterol levels and atopic diseases, and modulate the immune system (Chapman \& Gibson, 2011). Other benefits include cancer prevention, especially in the colon, and alleviation of food allergies (Chong, 2011). They have been shown in vitro to reduce the metabolic activity of harmful organisms (Mishra \& Prasad, 2005). Lactobacilli, a gram positive bacteria, are important probiotics that are devoid of cytochromes and prefer anaerobic conditions. Despite this, they are aero tolerant, fastidious, and strictly fermentative, and their main product is lactic acid (Stiles \& Holzapfel, 1997). Currently, many Llactobacilli strains have proved beneficial for health, yet their role as antioxidants needs further research (Mishra et al., 2015). Accordingly, this study aimed to evaluate the effects of Lactobacillus farciminis on the growth and antioxidant status of lambs.

\section{Materials and Methods}

This study was carried out with the permission of Kafkas University Animal Experiments Local Ethics Committee (Approval No: KAU-HAYDEK /2018-053). The experiment was conducted in Kafkas University Faculty of Veterinary Medicine, Prof. Dr. Ali Riza AKSOY Training, Research and Implementation Farm.

Lambs from Tuj breed were used in this study. The Tuj is a local sheep breed, raised in Kars, Ardahan and Igdir provinces of Turkey. Lambs were divided into four groups, regardless of gender, with a mean live weight of $7.81 \pm 0.50 \mathrm{~kg}$, and a total of 20 lambs were used. At the start of the experiment, the average age of the lambs was seven days. The experiment was conducted over 22 weeks with weaning occurring after the sixth week. All lambs were treated against internal and external parasites. The animals were exposed to natural daylight and kept under a temperature of $15 \pm 3^{\circ} \mathrm{C}$.

During the first six weeks of the study, the lambs with their mothers were housed in boxes $(1.8 \times 7 \times 6$ $\mathrm{m}$ ) equipped with automatic drinkers. The lambs were fed colostrum and pasture grass ad libitum. During this period, control (C) lambs received no further treatment. The other three groups were given $1 \mathrm{~g} /$ day/lamb (L1), $2 \mathrm{~g} /$ day/lamb (L2) or $4 \mathrm{~g} /$ day/lamb (L3) of Lactobacillus farciminis orally. The probiotic was given each day with a sterile syringe. Control lambs received distilled water, given in the same way. Feeding and the administration of the treatments occurred in the morning. The probiotic Biacton+® was obtained from a commercial company (Tarimsan Chemical A.Ş. Istanbul, Turkey) and had a Lactobacillus farciminis content of $5 \times 10^{9} \mathrm{CFU} / \mathrm{g}$. During the subsequent 16 weeks, all the lambs were pastured in Kars province with their mothers. The animals were taken to the pasture between $07 \mathrm{~h} 00$ and $12 \mathrm{~h} 00$ and between $13 \mathrm{~h} 00$ and $19 \mathrm{~h} 00$.

Nutrient analysis of the pasture grass was determined according to the methods of the AOAC (AOAC, 2005). Neutral detergent fibre (NDF) and acid detergent fibre (ADF) were determined according to Goering \& Van Soest (1970).

For the first six weeks of the study, BW was recorded weekly. Subsequently, BW was recorded monthly. Bodyweight gain (BWG) was calculated as the difference between BW measurements.

At the sixth week of the study and at the end of the experiment, blood samples were collected from the Vena jugularis of the lambs into tubes that contained anticoagulant (EDTA). Samples were centrifuged at $3000 \mathrm{rpm}$ for 15 minutes, and stored at $-20^{\circ} \mathrm{C}$ until the analyses were carried out. Superoxide dismutase, GPx and CAT antioxidant enzyme activities in plasma were determined by an ELISA device (Epoch, Biotek, USA) using commercial kits (Cayman Chemical Company, USA). The analysis of whole blood reduced GSH was done colorimetrically (Epoch, Biotek, USA) according to Beutler et al. (1963). The MDA in plasma was determined by the method of Yoshioko et al. (1979), ceruloplasmin by the method of Colombo \& Ricterich (1964) and albumin and total protein levels by a commercial test kit (Biolabo, Maizy, France). The NO level in serum was established according to Miranda et al. (2001). The amount of globulin was determined by subtraction of the albumin from the total protein (Doumas et al., 1971).

Repeated measures analysis of variance (ANOVA) was used to analyse effects of treatment, time and their interaction on BW and BWG. The test of simple effects with Bonferroni correction of the probability levels was used for the comparison of means. A one-way ANOVA was used in analysing the remaining measurements, and polynomial contrasts were used to assess the effects of the level of probiotic. A $P$-value of $<0.05$ was regarded as indicating a non-zero effect. All statistical analyses were performed using the IBM SPSS Statistics for Windows, version 23.0 (IBM Corporation, Armonk, New York, USA). 


\section{Results and Discussion}

When the nutrient content of the feed was examined, the dry matter (DM) content of pasture grasses was $92.1 \%$, crude protein (CP) was $9.13 \%$, and crude ash (CA) content was $7.6 \%$. Acid detergent fibre and NDF contents were $38.70 \%$ and $62.60 \%$, respectively. The metabolic energy (ME) level was determined as $1767 \mathrm{kcal} / \mathrm{kg}$. Calcium and $\mathrm{P}$ contents were $0.65 \%$ and $0.16 \%$, respectively (Table 1 ).

During the initial six weeks, the interaction of treatment with time effect on BW was statistically significant, which meant that the BW increase with time was different between groups (Table 1). According to the test of simple effects, a significant difference between groups emerged at week 6 . The average BW of lambs in L1 was significantly higher than that of C, with L2 and L3 being intermediate and not different from either extreme. As would be expected, the lambs in all groups increased in weight over time $(P<0.001)$.

According to the simple effect analysis, the fluctuations in BWG over time were random, except for lambs in L3, which displayed a marked increase in growth rate from week 5 to week 6 . Between weeks 2 and 3, the BWG of lambs in L2 was significantly greater than those in C. The lambs in L1 and L3 were intermediate between these extreme between weeks 2 and 3 and not different from either value. Between the 5th and 6th weeks, the average BWG was higher for lambs in L3 than that of their counterparts in C, with the lambs in L1 and L2 not being different from either extreme.

Table 1 Influence of the level of probiotic supplementation on bodyweight and bodyweight gain in Tuj lambs between one and seven weeks old ${ }^{1}$

\begin{tabular}{|c|c|c|c|c|c|c|c|}
\hline & \multirow[b]{2}{*}{$\mathrm{C}$} & \multirow[b]{2}{*}{ L1 } & \multirow[b]{2}{*}{ L2 } & \multirow[b]{2}{*}{ L3 } & \multicolumn{3}{|c|}{$P$-value } \\
\hline & & & & & Time & Treatment & $\begin{array}{c}\text { Time } \mathrm{x} \\
\text { treatment }\end{array}$ \\
\hline \multicolumn{8}{|c|}{ Body weight, kg } \\
\hline Initial & $7.73 \pm 0.69^{F}$ & $7.96 \pm 1.24^{G}$ & $7.99 \pm 1.22^{\mathrm{G}}$ & $7.57 \pm 1.12^{G}$ & \multirow{7}{*}{$<0.001$} & \multirow{7}{*}{0.506} & \multirow{7}{*}{$<0.001$} \\
\hline 1st week & $8.98 \pm 0.56^{\mathrm{E}}$ & $10.05 \pm 1.17^{\mathrm{F}}$ & $10.19 \pm 1.44^{F}$ & $9.32 \pm 1.21^{\mathrm{F}}$ & & & \\
\hline 2nd week & $11.06 \pm 0.75^{\mathrm{D}}$ & $12.54 \pm 1.05^{\mathrm{E}}$ & $11.90 \pm 1.46^{\mathrm{E}}$ & $11.54 \pm 1.21^{\mathrm{E}}$ & & & \\
\hline 3rd week & $12.16 \pm 0.82^{C}$ & $14.57 \pm 1.05^{\mathrm{D}}$ & $14.14 \pm 1.76^{\mathrm{D}}$ & $13.51 \pm 1.31^{\mathrm{D}}$ & & & \\
\hline 4th week & $14.25 \pm 0.87^{\mathrm{B}}$ & $17.50 \pm 0.88^{C}$ & $16.25 \pm 1.91^{\mathrm{C}}$ & $15.68 \pm 1.36^{\mathrm{C}}$ & & & \\
\hline 5th week & $16.29 \pm 0.94^{\mathrm{A}}$ & $20.04 \pm 0.95^{\mathrm{B}}$ & $18.18 \pm 1.81^{\mathrm{B}}$ & $18.06 \pm 1.60^{\mathrm{B}}$ & & & \\
\hline 6th week & $18.12 \pm 1.08^{\mathrm{b}, \mathrm{A}}$ & $23.50 \pm 1.01^{\mathrm{a}, \mathrm{A}}$ & $21.66 \pm 1.44^{\mathrm{ab}, \mathrm{A}}$ & $22.71 \pm 1.16^{\mathrm{ab}, \mathrm{A}}$ & & & \\
\hline \multicolumn{8}{|c|}{ Body weight gain, kg } \\
\hline 0-1 week & $1.25 \pm 0.22$ & $2.08 \pm 0.32$ & $2.20 \pm 0.46$ & $1.75 \pm 0.23^{B}$ & \multirow{6}{*}{$<0.001$} & \multirow{6}{*}{0.004} & \multirow{6}{*}{0.142} \\
\hline 1-2 week & $2.07 \pm 0.49$ & $2.49 \pm 0.17$ & $1.70 \pm 0.23$ & $2.21 \pm 0.44^{\mathrm{B}}$ & & & \\
\hline 2-3 week & $1.10 \pm 0.19^{b}$ & $2.02 \pm 0.04^{\mathrm{ab}}$ & $2.24 \pm 0.42^{a}$ & $1.96 \pm 0.12^{\mathrm{ab}, \mathrm{B}}$ & & & \\
\hline 3-4 week & $2.09 \pm 0.50$ & $2.93 \pm 0.27$ & $2.10 \pm 0.18$ & $2.17 \pm 0.25^{\mathrm{B}}$ & & & \\
\hline 4-5 week & $2.04 \pm 0.30$ & $2.54 \pm 0.38$ & $1.92 \pm 0.69$ & $2.38 \pm 0.56^{\mathrm{AB}}$ & & & \\
\hline 5-6 week & $1.83 \pm 0.34^{b}$ & $3.45 \pm 0.24^{\mathrm{ab}}$ & $3.48 \pm 0.67^{\mathrm{ab}}$ & $4.64 \pm 0.80^{\mathrm{a}, \mathrm{A}}$ & & & \\
\hline
\end{tabular}

'Data represent mean values of 5 replicates per treantment

C: control, L1: $1 \mathrm{~g}$ probiotic /lamb/day, L2: $2 \mathrm{~g}$ probiotic /lamb/day, L2: $4 \mathrm{~g}$ probiotic /lamb/day

a,b, A,B Within a column, means with common uppercase superscript were not different with probability $P=0.05$, and within a row means with common lowercase superscript were not different with probability $P=0.05$

No effect of the probiotic treatment or the interaction of treatment with time was observed (Table 2) during the grazing period, As expected, average BW increased significantly in every four-week period for the lambs in all of the groups. In addition, the average BWG was significantly higher between weeks 14 and 18 for the lambs in L3 compared with the subsequent weeks. Otherwise, the lambs' growth rates over time were consistent throughout the grazing period.

Responses in BW and BWG to probiotic supplementation were variable. Hillal et al. (2011) found that probiotic supplementation increased feed intake, perhaps through an effect of digestibility, but did not affect 
Table 2 Influence of the level of probiotic supplementation on bodyweight and bodyweight gain in Tuj lambs between seven and 23 weeks old ${ }^{1}$

\begin{tabular}{|c|c|c|c|c|c|c|c|}
\hline & \multirow[b]{2}{*}{ C } & \multirow[b]{2}{*}{ L1 } & \multirow[b]{2}{*}{ L2 } & \multirow[b]{2}{*}{ L3 } & \multicolumn{3}{|c|}{ Significance } \\
\hline & & & & & Time & Treatment & $\begin{array}{c}\text { Time } \mathrm{x} \\
\text { treatment }\end{array}$ \\
\hline \multicolumn{8}{|c|}{ Bodyweight, kg } \\
\hline week 10 & $26.42 \pm 1.74^{\mathrm{D}}$ & $30.08 \pm 1.73^{\mathrm{D}}$ & $30.25 \pm 2.67^{D}$ & $29.36 \pm 1.95^{\mathrm{D}}$ & \multirow{4}{*}{$<0.001$} & \multirow{4}{*}{0.365} & \multirow{4}{*}{0.267} \\
\hline week 14 & $32.30 \pm 1.85^{\mathrm{C}}$ & $34.90 \pm 2.15^{\mathrm{C}}$ & $36.10 \pm 2.32^{\mathrm{C}}$ & $37.20 \pm 1.56^{\mathrm{C}}$ & & & \\
\hline week 18 & $36.60 \pm 1.73^{\mathrm{B}}$ & $39.30 \pm 2.37^{B}$ & $40.80 \pm 2.61^{B}$ & $42.10 \pm 2.12^{B}$ & & & \\
\hline week 22 & $40.20 \pm 0.94^{\mathrm{A}}$ & $45.30 \pm 1.54^{\mathrm{A}}$ & $44.80 \pm 3.02^{\mathrm{A}}$ & $46.30 \pm 2.46^{\mathrm{A}}$ & & & \\
\hline \multicolumn{8}{|c|}{ Bodyweight gain, $\mathrm{kg}$} \\
\hline $6-10$ weeks & $8.29 \pm 1.24$ & $6.58 \pm 1.28$ & $8.58 \pm 1.53$ & $6.65 \pm 1.28^{\mathrm{AB}}$ & \multirow{4}{*}{$<0.001$} & \multirow{4}{*}{0.775} & \multirow{4}{*}{0.299} \\
\hline $10-14$ weeks & $5.87 \pm 0.92$ & $4.81 \pm 0.67$ & $5.85 \pm 0.57$ & $7.83 \pm 0.94^{\mathrm{A}}$ & & & \\
\hline $14-18$ weeks & $4.30 \pm 0.20$ & $4.40 \pm 0.43$ & $4.70 \pm 0.44$ & $4.90 \pm 0.81^{B}$ & & & \\
\hline 18 - 22 weeks & $3.60 \pm 1.13$ & $6.00 \pm 1.14$ & $4.00 \pm 0.52$ & $4.20 \pm 0.60^{B}$ & & & \\
\hline
\end{tabular}

${ }^{1}$ Data represent mean values of 5 replicates per treantment,

C: control, L1: $1 \mathrm{~g}$ probiotic /lamb/day, L2: $2 \mathrm{~g}$ probiotic /lamb/day, L3: $4 \mathrm{~g}$ probiotic /lamb/day

a,b, $A, B$ Within a column, means with common uppercase superscript were not different with probability $P=0.05$, and within a row means with common lowercase superscript were not different with probability $P=0.05$

BWG. Bodyweight and BWG values increased with the use of Saccharomyces cerevisiae in Awassi lambs (Haddad \& Goussous, 2005). Probiotics were also reported to enhance digestion and FCR and improve BWG in young ruminants (Robinson, 2002). Moreover, BWG value increased with the use of Saccharomyces cerevisiae in cattle diets, whereas the final BWG and average BWG were not affected (Gümüş \& Şehu, 2016). Alhidary et al. (2016) reported that direct-fed microbial supplementation in grazing Awassi lambs had a positive impact on BWG, whereas Saleem et al. (2017) stated that the effect of probiotic additive on BW and BWG in the preweaning period was not significant. However, its effect on BW and BWG in the period after weaning was statistically significant. Hassan et al. (2019) reported that the use of Ruminococcus flavefaciens in Baki lambs affected final BW and daily BWG. However, Kafilzadeh et al. (2019) stated that probiotic supplementation did not affect BW of sheep at the end of their study. Probiotic supplementation in powder or liquid form increased in vitro DM digestibility, nutrient digestibility and daily BWG for lambs (Hassan et al., 2019). Khattab et al. (2020) reported that supplementing sheep fed with Atriplex hay-based feeds with probiotic bacteria played a role in improving weaning weight, average BWG and the health status of the lambs. Tekce et al. (2021) investigated the effects of various levels of probiotics, yeast and mixtures on fattening performance, visceral weights and meat quality of Anatolian Merino lambs, and found that BW and BWG were affected statistically by the treatments. When these studies were examined, the positive effect of probiotic supplementation was seen in some studies, but the effects were negative in others. These variation may be due to differences in the probiotics, animal species, growth stage, environmental conditions and probiotic additive levels.

Probiotic bacteria increase feed utilization for growth in several ways. For example, they can produce or stimulate enzymes. They can also stimulate the immune system, reduce the $\mathrm{pH}$ of the environment by producing organic acids such as lactic acid, acetic acid and formic acid, and show inhibitory effects on pathogens such as E.coli and Salmonella spp (Asku \& Sulu, 2005). The use of lactic acid-producing Streptococcus bovis and Lactobacillus with Propionibacterium acnes or Aspergillus oryzae increased papillae development and production of essential fatty acids in the rumen (Wallace \& Newbold, 2007). Probiotic fungi and yeasts that are used as feed additives consume oxygen in the rumen and maintain the anaerobic environment. Low oxygen concentration stimulate the increase in the density of anaerobic bacteria in the rumen and ensure the maintenance of the rumen $\mathrm{pH}$ (Asku \& Sulu, 2005). In addition to their use in young animals, probiotics are often used to develop digestive functions in adult ruminants (Sun et al., 2010).

After six weeks of probiotic supplementation, the serum MDA exhibited a significant cubic response $(P$ $<0.001)$ with the change from the untreated control to L1 being relatively small, followed by a much larger change from L1 to L2 with the change from L2 to L3 again being smaller (Table 3). With the increased amount of probiotic that was provided to the lambs, the NO in their blood increased linearly. Responses of 
SOD and GPx to probiotic supplementation were quadratic, increasing with the amount of Lactobacillus farciminis that was provided. Ceruloplasmin, albumin, total protein and globulin levels were not affected by the treatments after six weeks.

Table 3 Influence of the level of probiotic supplementation on antioxidant status of seven-week old Tuj lambs $^{1}$

\begin{tabular}{|c|c|c|c|c|c|c|c|c|}
\hline & \multirow{2}{*}{ C } & \multirow{2}{*}{ L1 } & \multirow{2}{*}{ L2 } & \multirow{2}{*}{ L3 } & \multirow{2}{*}{ SE } & \multicolumn{3}{|c|}{$P$-value } \\
\hline & & & & & & Linear & Quadratic & Cubic \\
\hline $\mathrm{MDA}, \mu \mathrm{mol} / \mathrm{L}$ & 2.67 & 2.73 & 3.62 & 4.18 & 0.14 & $<0.001$ & $<0.001$ & $<0.001$ \\
\hline Nitric oxide, $\mu \mathrm{mol} / \mathrm{L}$ & 14.88 & 15.42 & 17.68 & 19.21 & 0.43 & $<0.001$ & 0.205 & 0.160 \\
\hline $\mathrm{GSH}, \mathrm{mg} / \mathrm{dL}$ & 40.86 & 41.06 & 42.14 & 43.09 & 0.37 & 0.022 & 0.595 & 0.749 \\
\hline $\mathrm{SOD}, \mathrm{U} / \mathrm{mL}$ & 1.34 & 2.03 & 3.06 & 4.24 & 0.25 & $<0.001$ & $<0.001$ & 0.297 \\
\hline CAT, nmol $/ \mathrm{min} / \mathrm{mL}$ & 32.78 & 33.75 & 35.00 & 35.46 & 0.42 & 0.016 & 0.741 & 0.757 \\
\hline $\mathrm{GPx}, \mathrm{nmol} / \mathrm{min} / \mathrm{mL}$ & 284.65 & 293.52 & 305.10 & 338.66 & 4.92 & $<0.001$ & 0.001 & 0.198 \\
\hline Ceruloplasmin, mg/dL & 18.72 & 17.25 & 17.67 & 19.47 & 0.80 & 0.536 & 0.100 & 0.905 \\
\hline Albumin, $\mathrm{g} / \mathrm{dL}$ & 2.96 & 2.97 & 2.98 & 2.98 & 0.02 & 0.698 & 0.906 & 0.916 \\
\hline Total protein, $\mathrm{g} / \mathrm{dL}$ & 7.36 & 7.34 & 7.31 & 7.32 & 0.01 & 0.185 & 0.574 & 0.699 \\
\hline Globulin, g/dL & 4.40 & 4.37 & 4.32 & 4.33 & 0.02 & 0.298 & 0.692 & 0.767 \\
\hline
\end{tabular}

${ }^{1}$ Data represent mean values of 5 replicates per treatment

C: Control, L1: $1 \mathrm{~g}$ probiotic /lamb/day, L2: $2 \mathrm{~g}$ probiotic/lamb/day, L3: $4 \mathrm{~g}$ probiotic/lamb/day

MDA: malondialdehyde, GSH: glutathione, SOD: superoxide dismutase, CAT: catalase, GPx: glutathione peroxidase

At the 22nd week of the study, the changes in serum MDA and NO levels were cubic $(P<0.001$ and $P=0.006$, respectively) with the changes from the untreated control to $L 1$ being relatively small, followed by a much larger change from L1 to L2, with the change from L2 to L3 again being smaller (Table 4). This pattern of response was similar to that shown in the MDA levels when the lambs were seven weeks old. Likewise, the responses of SOD and GPx were quadratic $(P<0.001$ and $P=0.023$, respectively) rising at an increasing rate. There was a linearly increasing $(P<0.001)$ response in CAT to the level of probiotic. However, GSH, ceruloplasmin, albumin, total protein and globulin were not affected by the level of probiotic that was provided.

Table 4 Influence of the level of probiotic supplementation on antioxidant status of Tuj lambs after 22 weeks

\begin{tabular}{|c|c|c|c|c|c|c|c|c|}
\hline & \multirow[b]{2}{*}{$\mathrm{C}$} & \multirow[b]{2}{*}{ L1 } & \multirow[b]{2}{*}{ L2 } & \multirow[b]{2}{*}{ L3 } & \multirow[b]{2}{*}{ SE } & \multicolumn{3}{|c|}{$P$-values } \\
\hline & & & & & & Linear & $\begin{array}{l}\text { Quadra- } \\
\text { tic }\end{array}$ & Cubic \\
\hline MDA, $\mu \mathrm{mol} / \mathrm{L}$ & 2.65 & 2.68 & 3.78 & 3.91 & 0.13 & $<0.001$ & 0.097 & $<0.001$ \\
\hline Nitric oxide, $\mu \mathrm{mol} / \mathrm{L}$ & 14.72 & 15.37 & 18.06 & 18.66 & 0.40 & $<0.001$ & 0.921 & 0.006 \\
\hline $\mathrm{GSH}, \mathrm{mg} / \mathrm{dL}$ & 40.74 & 40.91 & 41.57 & 41.83 & 0.34 & 0.231 & 0.947 & 0.784 \\
\hline $\mathrm{SOD}, \mathrm{U} / \mathrm{mL}$ & 1.38 & 1.94 & 2.91 & 4.17 & 0.24 & $<0.001$ & $<0.001$ & 0.591 \\
\hline $\mathrm{CAT}, \mathrm{nmol} / \mathrm{min} / \mathrm{mL}$ & 29.63 & 31.58 & 34.56 & 35.21 & 0.62 & $<0.001$ & 0.396 & 0.330 \\
\hline $\mathrm{GPx}, \mathrm{nmol} / \mathrm{min} / \mathrm{mL}$ & 287.02 & 290.82 & 311.50 & 327.05 & 3.86 & $<0.001$ & 0.023 & 0.051 \\
\hline Ceruloplasmin, mg/dL & 18.55 & 17.52 & 17.71 & 18.87 & 0.53 & 0.826 & 0.345 & 0.962 \\
\hline Albumin, g/dL & 2.93 & 2.99 & 3.00 & 2.97 & 0.02 & 0.570 & 0.358 & 0.946 \\
\hline Total protein, g/dL & 7.34 & 7.28 & 7.30 & 7.30 & 0.01 & 0.433 & 0.261 & 0.469 \\
\hline Globulin, g/dL & 4.40 & 4.29 & 4.29 & 4.33 & 0.02 & 0.370 & 0.173 & 0.742 \\
\hline
\end{tabular}


C: control, L1: $1 \mathrm{~g}$ probiotic /lamb/day, L2: $2 \mathrm{~g}$ probiotic /lamb/day, L3: $4 \mathrm{~g}$ probiotic/lamb/day MDA: malondialdehyde, GSH: glutathione, SOD: superoxide dismutase, CAT: catalase, GPx: glutathione peroxidase

Bacteria with probiotic properties have important antioxidant abilities in vivo and in vitro (Landis \& Tower, 2005; Persichetti et al., 2014). The bacteria Bifidobacterium animalis scavenged hydroxyl radicals and superoxide anion in vitro by improving antioxidant activity (Shen et al., 2011). The balance between oxidative stress and antioxidant status determines the susceptibility of organ systems to oxidative stress. Antioxidant capacity is defined as the level of presence of substances that react quickly with radicals and prevent the autoxidation/peroxidation progress (Dündar \& Aslan, 1999). Endogenous antioxidants consist of non-enzymatic and enzymatic antioxidants. Glutathione, albumin and ceruloplasmin are non-enzymatic antioxidants. Glutathione reductase, SOD, CAT and GPx are enzymatic antioxidants that form the enzymatic line of defence (Egea et al., 2020; Sies \& Jones, 2020). Superoxide dismutase is the first line of the antioxidant defence system, and plays a critical role in destroying superoxide radicals (Baldissera et al., 2017). Glutathione peroxidase is located in the cytoplasm of cells and protects cells against oxidative damage caused by hydrogen peroxide (Brodin et al., 2015). Hydrogen peroxide and hydroxyl radicals are converted by CAT to water and oxygen. Glutathione prevents the conversion of haemoglobin to methemoglobin (Aydemir \& Karadağ Sarı, 2009). Nitric oxide is among the most important reactive nitrogen types. Vascular occlusions occur because of the decrease in NO bioactivity (Fukai et al., 2002). NO and oxygen radicals are extremely reactive and react rapidly to form nitrite, nitrate, and most importantly peroxynitrite anion (Singh et al., 2004). In the present study, the effect of probiotic supplementation on MDA, NO, GSH, SOD, GPx, and CAT was important throughout the experiment. Mousa et al. (2009) stated that the probiotic supplement to the feed of Barki sheep during the rearing period showed a significant increase in the total antioxidant capacity and decreased GSH on the 30th day after the addition. Peng et al. (2018) reported that the probiotic additive did not affect MDA and total antioxidant capacity values, but increased the SOD and GSH-Px values. Kafilzadeh et al. (2019) found that probiotic supplementation rarely affected the blood plasma metabolite content and enzyme activities of sheep. L. fermentum showed significant in vitro antioxidant capacity, which increased its total antioxidant potential (Persichetti et al., 2014). Thus, the results from the present study showing beneficial effects of the probiotic Lactobacillus farciminis on the antioxidant status of lambs are consistent with these previous investigations. Didarkhah and Vatandoost (2021) reported that glucose and triglyceride, total plasma protein concentrations and plasma albumin levels were not affected by probiotic additives that were provided in the feed.

\section{Conclusion}

In conclusion, the use of oral Lactobacillus farciminis affected the antioxidant status of lambs positively with minor effects on their growth. These effects suggest Lactobacillus farciminis provides a mechanism for protection against oxidative damage. In the light of the data obtained from this study, oral use of Lactobacillus farciminis is a safe way to protect lambs against the effects of oxidative stress. These results might increase profitability for sheep producers However, they should be supplemented with larger doseresponse studies to establish the minimum efficacious dose of Lactobacillus farciminis.

\section{Acknowledgments}

This study was funded by Kafkas University Coordination of Scientific Research Projects, project number 2019TS-14. We would like to extend our deepest thanks to Yusuf Kaya from Tarımsan Inc., who provided probiotic.

\section{Authors' Contributions}

ÖDA, GY and SUB (ORCID: 0000-0003-4532-6795; 0000-0002-1003-9254; 0000-0001-9533-0165, respectively) executed the experiment. PA (ORCID: 0000-0001-6572-4219) analysed the collected data statistically. ÖDA completed the manuscript. SUB analysed the manuscript critically. AKT (ORCID:0000-0002-4541-0738) reviewed the final compilation of the manuscript. SUB helped in preparing the manuscript. EA and MZ (ORCID: 0000-0002-3288-2058; 0000-0003-1691-7764, respectively) contributed to the design and execution of the study. GY, ÖDA, OM (ORCID: 00000002-3399-0667) and AKT were in charge of laboratory analyses. ÖDA was responsible for supervising and writing the manuscript.

\section{Conflict of Interest Declaration}

The authors declare that they have no conflict of interest.

\section{References}

Aarestrup, F.M., Bager, F. \& Andersen, J.S., 2000. Association between the use of avilamycin for growth promotion and the occurrence of resistance among Enterococcus faecium from broilers: Epidemiological study and changes over time. Microb. Drug Resist. 6, 71-75. DOI: 10.1089/mdr.2000.6.71 
Alhidary, I.A., Abdelrahman, M.M. \& Khan, R.U., 2016. Comparative effects of direct-fed microbials alone or with a trace minerals supplements on the productive performance, blood metabolites, and antioxidant status in grazing Awassi lambs. Environ. Sci. Pollut. Res. 23(24), 25218-25223. DOI: 10.1007/s11356-016-7684-z

Antunovic, Z., Speranda, M., Liker, B., Seric, V., Steiner Z. \& Domacinovic, M., 2005. Influence of feeding the probiotic Pioneer PDFM® to growing lambs on performances and, blood composition. Acta Vet. 55(4), 287-300. DOI: 10.2298/AVB0504287A

AOAC, 2005. Official methods of analysis of AOAC International. 18th ed. AOAC, Gaithersburg, Maryland, USA

Aşan, M. \& Özcan, N., 2006. Kanatlı beslemede inulinin prebiyotik olarak önemi. Hayvansal Üretim 47(2), 48-53.

Asku, D.S. \& Sulu, N., 2005. Ruminantlarda probiyotiklerin kullanımı ve rumene etkileri. Kafkas Univ. Vet. Fak. Derg. 11(1), 93-98

Aydemir, B. \& Karadağ Sarı, E., 2009. Antioksidanlar ve buyume faktorleri ile ilişkisi. Kocatepe Vet. J. 2 (2), 56-60.

Baldissera, M.D., Souza, C.F., Grando, T.H., Dolci, G.S., Cossetin, L.F., Moreira, K.L.S., Da Veiga, M.L., Da Rocha, M.I.U.M., Boligon, A.A., De Campos, M.M.A., Stefani, L.M., Da Silva, A.S. \& Monteiro, S.G., 2017. Nerolidolloaded nanospheres prevent hepatic oxidative stress of mice infected by Trypanosoma evansi. Parasitology 144, 148-157.

Beutler, E., Duron, O. \& Kelly, B.M., 1963. Improved method for the determination of blood glutathione. J. Lab. Clin. Med. 61, 882-888.

Brodin, O., Eksborg, S., Wallenberg, M., Asker-Hagelberg, C., Larsen, E.H., Mohlkert, D., Lenneby-Helleday, C., Jacobsson, H., Linder, S., Misra, S. \& Bjornstedt, M., 2015. Pharmacokinetics and toxicity of sodium selenite in the treatment of patients with carcinoma in a phase I clinical trial: The SECAR study. Nutrients 7, 4978-4994.

Chapman, C.M. \& Gibson, G.R., 2011. Health benefits of probiotics: Are mixtures more effective than single strains? Eur. J. Nutr. 50, 1-17.

Chong, E.S., 2014. A potential role of probiotics in colorectal cancer prevention: Review of possible mechanisms of action. World J. Microbiol. Biotechnol. 30(2), 351-374. DOI: 10.1007/s11274-013-1499-6

Cimrin, T., Tunca, R.I., Avsaroglu, M.D., Ayasan, T. \& Kücükersan, S., 2020. Effects of an antibiotic and two phytogenic substances (cinnamaldehyde and 1,8-cineole) on yolk fatty acid profile and storage periodassociated egg lipid peroxidation level. R. Bras. Zootec. 49:e20190270.

Colombo, J.P. \& Richterich, R., 1964. Zur bestimmung des caeruloplasmin im plasma [on the determination of ceruloplasmin in plasma]. Schweiz Med. Wochenschr. 23, 715-720.

Didarkhah, M. \& Vatandoos, T.M., 2021. The effect of probiotic and prebiotic supplements on growth performance, blood parameters and skeletal growth of Baluchi male lambs. Iranian J. Anim. Sci. Res. 12(4): 411-422. DOI: 10.22067/ijasr.v12i4.75166

Diler, A., 2007. Probiyotik + enzim kombinasyonunun esmer ırkı buzağılarda yemden yararlanma ve büyüme performansı üzerine etkileri. Yüksek Linans Tezi. Atatürk Üniv Fen Bilimleri Enstitüsü, Z Zootekni Programı, Erzurum.

Doumas, B.T., Watson, W.A. \& Biggs, H.G., 1971. Albumin standards and the measurement serum albumin with bromcresol green. Clin. Chim. Acta. 31, 87-96.

Durna Aydin, O., Yıldız, G. \& Merhan, O., 2021. Effects of probiotic (Lactobacillus farciminis) supplementation in quail (Coturnix coturnix japonica) rations on growth performance, blood antioxidant capacity and cecal some shortchain fatty acid concentrations. Kafkas Univ. Vet. Fak. Derg. 27 (1), 15-20. DOI: 10.9775/kvfd.2020.24541

Dündar, Y. \& Aslan, R., 1999. Hucre molekuler statusunun anlaşılması ve fizyolojik onem acısından radikaller, antioksidanlar. Insizyon Cerrahi Tıp Bil. Derg. 2 (2), 134-142.

Egea, G., Jimenez-Altayo, F. \& Compuzano, V., 2020. Reactive oxygen species and oxidative stress in the pathogenesis and progression of genetic diseases of the connective tissue. Antioxidants 9(10), 1013. DOI:10.3390/antiox9101013

FAO \& WHO, 2002. Guidelines for the evaluation of probiotics in food: Report of a joint FAO/WHO working group on drafting guidelines for the evaluation of probiotics in food. London, Ontario, Canada.

Fukai, T., Folz, R.J., Landmesser, U. \& Harrison, D.G., 2002. Extracellular superoxide dismutase and cardiovascular disease. Cardiovasc. Res. 55, 239-249. DOI: 10.1016/s0008-6363(02)00328-0

Goering, H. \& Van Soest, P.J., 1970. Forage fiber analyses (apparatus, reagents, procedures, and some applications). USDA, Agricultural Research Service, Washington, USA.

Gümüş, H. \& Şehu, A., 2016. Effect of yeast culture supplementation to beef rations on feedlot performance, some rumen and blood parameters. Ankara Üniv. Vet. Fak. Derg. 63, 39-46. DOI: 10.1501/Vetfak_0000002707

Haddad, S.G. \& Goussous, S.N., 2005. Effect of yeast culture supplementation on nutrient intake, digestibility and growth performance of Awassi lambs. Anim. Feed. Sci. Technol. 118, 343-348. DOI: 10.1016/j.anifeedsci.2004.10.003

Hassan, A., Gado, H. Anele, U.Y., Berasain, M.A.M. \& Salem, A.Z.M., 2019. Influence of dietary probiotic inclusion on growth performance, nutrient utilization, ruminal fermentation activities and methane production in growing lambs. Anim. Biotechnol. 31 (4), 365-372. DOI: 10.1080/10495398.2019.1604380

Hillal, H., El-Sayaad, G. \& Abdella, M., 2011. Effect of growth promoters (probiotics) supplementation on performance, rumen activity and some blood constituents in growing lambs. Arch. Anim. Breed 54(6), 607-617. DOI: 10.5194/aab-54-607-2011

Kafilzadeh, F., Payandeh, S., Gómez-Cortés, P., Ghadimi, D., Schiavone, A. \& Marín, A.L.M., 2019. Effects of probiotic supplementation on milk production, blood metabolite profile and enzyme activities of ewes during lactation, Italian J. Anim. Sci. 18(1), 134-139, DOI: 10.1080/1828051X.2018.1496040 
Khattab, I.M., Abdel-Wahed, A.M., Khattab, A.S., Anele, U.Y., El-Keredy, A. \& Zaher, M., 2020. Effect of dietary probiotics supplementation on intake and production performance of ewes fed Atriplex hay-based diet. Livest. Sci. 237, 104065. https://doi.org/10.1016/j.livsci.2020.104065

Landis, G.N. \& Tower, J., 2005. Superoxide dismutase evolution and life span regulation. Mech. Ageing Dev. 126, 365379, DOI: 10.1016/j.mad.2004.08.012

Miranda, K.M., Espey, M.G. \& Wink, D.A., 2001. A rapid, simple spectrophotometric method for simultaneous detection of nitrate and nitrite. Nitric Oxide 5(1), 62-71. DOI: 10.1006/niox.2000.0319

Mishra, V., Shah, C., Mokashe, N., Chavan, R., Yadav, H. \& Prajapati, J., 2015. Probiotics as potential antioxidants: A systematic review. J. Agric. Food Chem. 63(14), 3615-26. DOI: 10.1021/jf506326t

Mousa, S., Elsayed, A., Marghani, B. \& Ateya, A., 2019. Effects of supplementation of Bacillus spp. on blood metabolites, antioxidant status, and gene expression pattern of selective cytokines in growing Barki lambs. J. Adv. Vet. Anim. Res. 6(3), 333-340. DOI: 10.5455/javar.2019.f351

Peng, J., Kai, C., Ma, M., Tao, W., Fan, W. \& Weny, Y., 2018. Infuence of dietary supplementation with Bacillus licheniformis and Saccharomyces cerevisiae as alternatives to monensin on growth performance, antioxidant, immunity, ruminal fermentation and microbial diversity of fattening lambs. Sci. Rep. 8(1),16712. DOI: 10.1038/s41598-018-35081-4

Persichetti, E., De Michele, A., Codini, M. \& Traina, G., 2014. Antioxidative capacity of Lactobacillus fermentum LF31 evaluated in vitro by oxygen radical absorbance capacity assay. Nutrition 30(7-9), 936-938. DOI: 10.1016/j.nut.2013.12.009

Robinson, P.H., 2002. Yeast products for growing and lactating dairy cattle: Impact on rumen fermentation and performance. Dairy Rev. 9, 1-4.

Saleem, A.M, Zanouny, A.I. \& Singer, A.M., 2017. Growth performance, nutrients digestibility, and blood metabolites of lambs fed diets supplemented with probiotics during pre-and post-weaning period. Asian-Australasian J. Anim. Sci. 30(4), 523. Doi:10.5713/ajas.16.0691

Shen, Q., Shang, N. \& Li, P., 2011. In vitro and in vivo antioxidant activity of Bifidobacterium animalis 01 isolated from centenarians. Curr. Microbiol. 62(4), 1097-1103. DOI: 10.1007/s00284-010-9827-7

Sies, H., \& Jone, D.P., 2020. Reactive oxygen species (ROS) as pleiotropic physiological signalling agents. Nat. Rev. Mol. Cell Bio. 21, 363-383.

Singh, K.P., Mohan, D., Sinha, S., \& Dalwani, R., 2004. Impact assessment of treated/untreated wastewater toxicants discharged by sewage treatment plants on health, agricultural, and environmental quality in the wastewater disposal area. Chemosphere 55(2), 227-255.

Stiles, M.E., \& Holzapfel, W.H., 1997. Lactic acid bacteria of foods and their current taxonomy. Int. J. Food Microbiol. 36, $1-29$.

Sun, P., Wang, J.Q. \& Zhang, H.T., 2010. Effects of Bacillus subtilis natto on performance and immune function of preweaning calves. J. Dairy Sci. 93, 5851-5855. DOI: 10.3168/jds.2010-3263

Tekce, E., Bayraktar, B., Aksakal, V., Dertli, E., Kamiloğlu, A., Karaalp, M., Tiimurkaan, S. \& Gül, M., 2021. Response of probiotics and yeast added in diff erent doses to rations of Anatolian Merino lambs on fattening performance, meat quality, duodenum and rumen histology. Kafkas Univ. Vet. Fak. Derg. 27 (1), 57-65. DOI: $10.9775 / \mathrm{kvfd} .2020 .24747$

Wallace, R.J. \& Newbold C.J., 2007. Microbial feed additives for ruminants. In: R.J. Wallace \& A. Chesson.(eds). Biotechnology in animal feeds and animal feeding. Rowett Rerearch Institute, Aberdeen, Scotland.

Yoshioko, T., Kawada, K., Shimada, T. \& Mori, M., 1979. Lipid peroxidation in maternal and cord blood and protective mechanism against activated-oxygen toxicity in the blood. Am. J. Obstet. Gynecol. 135, 372-376. DOI: 10.1016/0002-9378(79)90708-7 